\title{
THE COMPLAINT RESOLUTION PROJECT
}

\section{LOIS MACLEAN and JOHN MCNIVEN ${ }^{*}$}

The authors describe the new complaint resolution project at the Law Society of Alberta, which handles some of the clientlawyer and lawyer/lawyer complaints. Because the legal profession is selfgoverning, the Law Society must have a means of protecting the public and regulating the conduct of its members. Under the Legal Profession Act, a process is in place that deals with written complaints in a very formal manner. The shortfalls of this formal process are the high levels of stress for the participants, the time required and the expense involved. The authors recognize, however, that the less formal process discussed is onty appropriate in some, and not all, cases.

This less formal process was tested during the Trial Project. The complaints officers offered complainants the less formal route when it was felt to be appropriate. The dispute resolution process that has emerged is neither traditional arbitration nor mediation, but rather a hybrid process, in which the complaints officer inserts himself or herself between the parties, and attempts to assist in reaching a settlement. The authors discuss common causes and types of complaints and then present the results of the Trial Project.

While it is perhaps 100 early for a definitive statistical assessment, it seems that the Trial Project has significantly reduced the number of formal complaints being dealt with by the Law Society. Additionally, the project seems to have been wellreceived by the bar. At the same time, the authors want to remain open to criticism and discuss some concerns that have been voiced about the new process and the complaints officers.

The authors then canvass informal complaints procedures that have been instituted by other law societies, Canadian and otherwise, and compare the experiences and results of those projects. In conclusion, the authors recount the overall favourable comments they have received as part of the Trial Project, and discuss the challenge for the Law Society in the future.
$L$ 'auteur décrit le nouveau projet de règlement des plaintes de la Law Society of Alberta, qui porte à la fois sur les plaintes opposant clients-avocats, et avocats entre eux. Parce que la profession juridique est autonome, l'ordre des avocats doit avoir un moyen de protéger le public. Auparavant, la Loi régissant les carrières juridiques prévoyait un processus qui traitait des plaintes écrites de façon très officielle. Mais ce processus présentait plusieurs inconvénients : un stress considérable pour les participants, des délais et des frais importants. Les auteurs reconnaissent toutefois qu'une approche moins officielle ne convient que dans certains cas.

Une approche de ce type a été mise à l'épreuve dans le cadre du Trial Project. Les agents de plaintes l'ont proposés dans les cas jugés appropriés. Le processus de résolution des différends qui en est issu n'est ni de l'arbitrage ni de la médiation au sens traditionnel, mais un processus hybride où les agents de plaintes $s$ 'interposent entre les parties et s'efforcent de les aider à trouver une solution. Les auteurs discutent de cas et de types de plaintes courants, et présentent les résultats du Trial Project.

Bien qu'il soit peut-être prématuré d'offir une évaluation statistique définitive, il semblerait que le projet ait considérablement réduit le nombre de plaintes officielles recu par le barreau. De plus, le projet semble bien accueilli par les avocats. Pourtant, les auteurs tiennent à rester ouverts aux critiques et $\dot{a}$ traiter de certaines des préoccupations qui ont été exprimées au sujet des nouveaux processus et des agents de plaintes.

Les auteurs examinent ensuite les procédures officieuses instituées par d'autres ordres d'avocats, au Canada et à l'étranger, et comparent les expériences et résultats ainsi obtenus. En conclusion, ils rappellent les commentaires favorables qu'ils ont recueillis dans le cadre du projet, et discute du défi qu'il présentera à l'ordre des avocats dans l'avenir.

\section{TABLE OF CONTENTS}

I. INTRODUCTION $\ldots \ldots \ldots \ldots \ldots \ldots \ldots \ldots \ldots$

II. THE TRADITIONAL PROCESS .............. 55

With assistance from Susan Billington. The authors are the complaints officers involved with the project. 


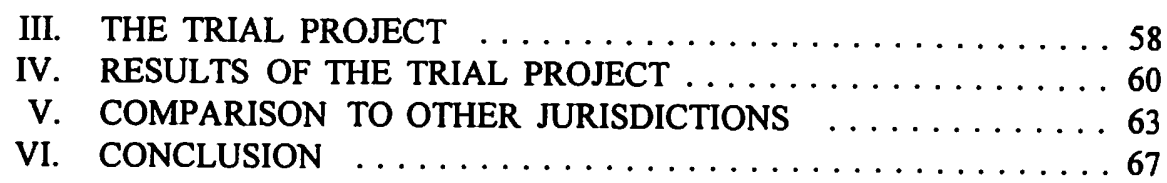

\section{INTRODUCTION}

The complaint resolution process was started on an experimental basis by the Law Society of Alberta in June 1994. It was prompted by the realization that in many cases, complaints against lawyers can and should be resolved without resort to the formal and sometimes lengthy complaint process dictated by the Legal Profession Act ${ }^{\prime}$ and the Rules of the Law Society. The experiment was undertaken to determine if an alternative complaint resolution process could be usefully developed and implemented. Our mandate has been to develop such a process and to utilize it in resolving complaints by client against lawyer or by lawyer against lawyer, where both the complainant and the lawyer consent to complaint resolution. When successful, we have been able to reduce the time and complexity of the complaint process for both the complainant and the lawyer and in many cases have assisted the parties to reach a resolution satisfactory to both.

\section{THE TRADITIONAL PROCESS}

As a self-governing profession, our professional association has a responsibility both to protect the public interest as well as to represent the interests of its members. To accomplish these objectives, the Law Society must have a system for dealing with professional misconduct (or allegations thereof) of its members and that in turn requires some means of receiving complaints made either by the public or by one lawyer against another. The system must then provide a means to investigate the complaint to determine whether or not there has been misconduct and, if so, to impose the appropriate penalties or directions. The Legal Profession Act establishes a formal and detailed system. Generally, the process is triggered by a written complaint being received by the Society. A written notice is then sent to the lawyer involved requesting a written response with an explanation or comments regarding the complaint. ${ }^{2}$ In certain circumstances, further investigation is necessary, but in the majority of cases, the exchange of correspondence forms the basis of the investigation. The Deputy Secretary then reviews the information and either dismisses the complaint, or refers it to a panel of benchers for further action. Complaints can be dismissed either by the Deputy Secretary, by a Bencher's Conduct Committee panel, or by a Bencher's Appeal Committee panel. Where the complaint is dismissed, the Deputy Secretary must (by the Rules of the Law Society) ${ }^{3}$ advise the complainant that he or she has the right to

R.S.A. 1980, c. L-9.1.

Ibid., s. 51.

Law Society of Alberta, Rules (Calgary: Law Society of Alberta), r. 85(7) states:

If the Secretary, pursuant to section 51 (3)(a) of the Act, directs that the matter reviewed be dismissed, the Secretary shall

(a) in the case of a complaint, notify the complainant of the dismissal and the reason for the dismissal and provide to the complainant instructions, as to how the complainant may 
appeal the dismissal and of the basic procedure to file the appeal. The appeal, if there is one, is also to the benchers. As a matter of policy (although not required by statute), the Society attempts to ensure that one of the lay benchers is part of each Appeal panel to ensure that the public's interests are represented.

For the year preceding the start of our trial project (1993), the Society received 1110 formal (written) complaints. The number of complaints has been consistently in that range for several years, with some slight increase. ${ }^{4}$ During that same year, the Deputy Secretary dismissed 684 complaints and the complainant appealed his or her dismissal in ninety-four cases. In well over one third of the complaints (429) the benchers were involved in some fashion, whether through the Conduct Committee, an Appeal Panel or a hearing. During that same year ninety-one complaints were directed to hearing and twenty-eight members of the Society were either found guilty or allowed to resign pending discipline proceedings.

During the 1993 calendar year the number of complaints files closed was 1000 . Those complaints dismissed were not all received in that calendar year, as many of those dismissed would have been received in the calendar year 1992 and many of those received in 1993 would have been dealt with in some fashion during 1994. Therefore, there is some overlap from year to year. However, the complaints statistics have been fairly consistent for the past few years. In considering the complaint files closed, the Law Society of Alberta Annual Report 1993 indicates that 981 complaints were dismissed either by the Deputy Secretary, the Conduct Committee or an Appeal Committee. ${ }^{5}$ However, this is somewhat misleading in that it includes files where an invitation was issued to the member, ${ }^{6}$ files which were referred to the Conduct Review Committee ${ }^{7}$ and files where an informal letter of reprimand was sent to the member. Of the complaints which are dismissed by the Society, the dismissal might be for a variety of reasons, including a lack of jurisdiction on the part of the Society, or because the lawyer had not in fact done anything wrong, or because the remedy was more appropriately civil in nature (for example a negligence claim). However, in many cases the complainant did not accept the reasons for the dismissal or did not believe that the

appeal the dismissal to the Appeal Committee, and

(b) in every case, notify the member of the dismissal.

- The number of complaint files for the last 5 years is as follows:

1990: 958

1991: 982

1992: 1,126

1993: 1,110

1994: 951

$5 \quad$ Law Society of Alberta, Law Society of Alberta Annual Report 1993 (Calgary: Law Society of Alberta, 1993) at 15 [hereinafter Annual Report 1993].

- An informal meeting between a bencher and a lawyer to review conduct which may not require discipline, but which evidenced or involved poor or questionable practice.

"The mandate of the Conduct Review Committee is to assess the remedial and preventive needs of individual members of the profession who come to the attention of the Committee as a result of inappropriate attitudes, legal incompetence, poor practice or administration habits, medical problems, or some combination of these factors." Quoted from the "Report of the Conduct Review Committee" in Annual Report 1993, supra note 5 at 16. 
complaint had been adequately listened to or investigated, and the dismissal was appealed.

The Annual Report 1993 recognized that there was a "continuing high level of dissatisfaction expressed by both the public and the profession in dealing with the complaint procedures of the Law Society." ${ }^{8}$ From the perspective of a lawyer responding to a complaint, the formal process is highly stressful, time-consuming and can be expensive if the lawyer chooses to retain counsel to assist in dealing with the complaint. Some members of the public have on occasion indicated the belief that the Society operated to protect lawyers or used other words to the effect that complaints were falling on deaf ears.

From the perspective of the benchers, the formal process is extremely timeconsuming because a high percentage of the complaints require hearings or appeals. A factor in this is the primarily written process of the formal complaint system.

In the Annual Report 1993, the Conduct Committee report states:

A recommendation was also made to the Benchers, and adopted but not yet implemented, to initiate a pilot project which would provide for a problem-solving activity at the outset of the complaint process for those complaints which can be identified as having an easy remedy available if the cooperation and participation of the member and the complainant can be acquired.'

Complaint resolution is viewed by the benchers as obviously being in the public interest, but it is also seen as being of assistance to lawyers. If concerns can be resolved in an expeditious fashion, that is more satisfactory to the complainant than a more timeconsuming and impersonal system. In many cases the complainant simply wants to know there is someone to listen to his or her concerns, discuss them and, if necessary, assist the complainant to deal with them.

It is obvious that not all complaints are amenable to informal resolution. One cannot, for example, informally resolve a complaint about a shortage of trust funds. There must always be a formal system to deal with allegations of conduct deserving of sanction. ${ }^{10}$ However, there are many complaints received by the Society which are more minor in nature and which are entirely suitable for informal resolution. Terminology differs between various provinces, but some law societies categorize this type of complaint as inadequate professional service, or sloppy practice. This type of complaint forms a

Annual Report 1993, ibid. at 15.

I Ibid.

10 The Legal Profession Act, supra note 1, s. 47 states in part:

47(1) For the purposes of this Act, any conduct of a member, arising from incompetence or otherwise, that

(a) is incompatible with the best interests of the public or of the members of the Society, or

(b) tends to harm the standing of the legal profession generally,

is conduct deserving of sanction, whether or not that conduct relates to the member's practice as a barrister and solicitor and whether or not that conduct occurs in Alberta. 
significant portion of the complaints which the Society receives, and often does not reflect conduct which is deserving of sanction or professional discipline, but which is an irritant to the solicitor/client relationship. Delay in communication or lack of understanding by either the solicitor or the client of the other's view of the problem are common examples of this type of problem. The dividing line between what can be informally resolved and what must be dealt with in the formal system has not yet (and probably cannot nor should not) be exactly defined. For example, a complaint of delay may be minor in nature and easily resolved, or it may be extremely serious and complicated by limitations or other factors. That issue will be discussed in more detail in the examination of the actual experience in the trial project.

\section{THE TRIAL PROJECT}

The complaint resolution process which has evolved during the experimental period is neither traditional mediation nor arbitration. As complaints officers we have to operate within the parameters of the Legal Profession Act, which includes a provision for the Secretary of the Society (or his delegate) to attempt resolution of a complaint, " but which also contains directions for the review and investigation of complaints through the formal process. ${ }^{12}$ A complaint cannot be dealt with on an "off the record" basis. One of the significant motivating factors in most complaints is that the complainant wants to register a complaint and wants someone to be aware that he or she does not believe he or she has been properly treated by the particular lawyer. That is a major part of the reason for the call to the Society in the first place, and if as complaint officers we then suggested that we could deal with their concerns only on an "off the record" basis, we would simply reinforce the public's belief that the Law Society is only there to protect lawyers. The complaints officers do not encourage complaints or reports, but as lawyers they are under the same obligation to report any serious misconduct as any other member of the Society. ${ }^{13}$ Having said that, the purpose of the complaints officers is to resolve complaints rather than to create more.

Complaints are made to the Law Society by way of letters, faxes, telephone calls and people attending at either the Calgary or Edmonton office wanting to discuss and possibly register their complaints. During the term of the experiment, both of the writers worked as part-time complaints officers, with one of us located in each of these cities. The Calgary officer handles the complaints against lawyers located south of Red Deer and the Edmonton officer handles complaints against lawyers located in Red Deer and north. If the complaint is originally received in writing, the letter is reviewed to determine whether or not the complaint seems to be one which would be suitable for us to try to resolve. If it appears suitable, then the complainant is contacted by the complaints officer to discuss the options which may be available and the possibility of informally attempting to resolve the complaint. If the original contact with the Society is by way of a telephone call, or an in-person visit from the complainant, then the

11 Ibid., s. 51(4).

$12 \quad$ Ibid., ss. 51-79.

13 Law Society of Alberta, Code of Professional Conduct (Calgary: Law Society of Alberta, 1995), c. 3 , r. 4. 
complaints officers attempt during the first discussion to consider with the complainant whether there is in fact any merit to the potential complaint and, if so, whether it is likely capable of resolution, or whether it should be put into the formal process.

As noted earlier, the dispute resolution processes employed by the complaints officers did not involve traditional arbitration or mediation techniques - the available time and the volume of complaints simply did not allow these to be utilized. In dealing with a complaint, we of course recognized the fundamental importance of identifying the complainant's goal in making the complaint and tried to understand what the complainant was attempting to achieve. Each complaint involved its own particular set of circumstances which in turn dictated the approach taken to attempt to resolve the situation.

In developing a dispute resolution process, what has emerged is a hybrid technique wherein we inserted ourselves between the complainant and the lawyer, listened to both and then attempted to try to assist the two to arrive at a settlement or resolution of the complaint. In some cases, all that was required was to assist in the better flow of information from the complainant to the lawyer, or vice versa. In others, a combination of listening, explaining, placating, hand-holding, negotiating and occasionally rendering an informal opinion were used. In many cases, we were able to suggest remedies outside the Law Society's complaint process entirely, such as taxation of an account or consideration of whether a second opinion might be appropriate. In some cases, providing general information about the functioning of the legal system, while not providing specific advice, was useful.

In most cases a complaint from a member of the public stems from a breakdown in solicitor-client communication. As a result, while in many cases the callers initially indicate that they wish to register a complaint, after some discussion, other alternatives may be more suitable. For example, clients may have unrealistic expectations about time frames, fees, the likelihood of success of a particular argument, etc. The complaints officers do not provide legal advice to callers, but in some cases enough information can be provided to allow the caller to go back to his or her own lawyer to discuss the concerns, having a better understanding of the entire situation. If the breakdown is past "fixing," it may be more appropriate to suggest that the complainant consider getting a second opinion, or to describe the process for transferring the file to a new lawyer. Frequently, assisting the complainant in getting on with resolving the original legal problem will avoid the filing of the formal complaint. If the complainant refuses to consider informal resolution or if all our efforts fail, the complaint is dealt with as a formal complaint.

In terms of the areas of law which generate complaints, family law is undoubtedly the single largest area and is the basis of roughly one half of the total calls (including general information inquiries) received. While there is some variation between Edmonton and Calgary, the other areas which generate calls are real estate, personal injury (particularly contingency agreement files), criminal law and wills and estates. One common thread in all of these areas is that clients are often not experienced in the legal system and frequently they are involved in complex legal proceedings for the first time. 
Often they either have not been given sufficient information to understand the legal complexities of their situation, or do not accept the advice which is being provided to them. Frequently too, clients may be somewhat intimidated by their lawyer or the legal system and are hesitant to question the professional upon whom they are relying for advice.

In all areas of law, certain types of complaints are frequently encountered. The most common complaints are those relating to fees. There are several variations of this complaint, such as an allegation that the amount billed was higher than the estimate, or that there was an unreasonable delay in billing and of course, when the fee is on a time spent basis, that the value of what the client has received is less that the "timespent" amount actually billed. While the Law Society does have jurisdiction over ethical issues related to legal fees, generally speaking, fee complaints are referred to the taxation office in the first instance. The provisions in the new Code of Professional Conduct, ${ }^{14}$ requiring greater information on fees, may reduce the number of fee-related complaints eventually, but any move in this direction is not yet apparent.

Other frequently encountered types of complaints include delay (failing to respond to communications or instructions) and disputes about solicitor's liens and the transfer of files. These are particularly contentious on contingency agreement files, where substantial disbursements are often incurred. A surprising number of complaints are received alleging that lawyers have failed to pay accounts arising from their practices. In a large number of complaint calls, the complainant expresses dissatisfaction with more than one aspect of his or her dealings with the individual lawyer. For example, complaints about lack of communication and failing to respond to telephone calls or letters are frequently mixed together with complaints about the amount of the fee charged.

\section{RESULTS OF THE TRIAL PROJECT}

The Law Society is in the process of establishing a database to provide better information on the number and type of calls received, but unfortunately the detailed information is not yet available. The nature and extent of record-keeping and the general office procedures of the complaints officers (as with the resolution process itself) have been evolving during the course of the first year's experience. One of the goals has been to resolve complaints where possible on an informal basis by way of telephone contact between the complainant and the lawyer. Given that informal format, the officers have tried to minimize paperwork and record-keeping as much as possible. Some records must obviously be kept of the work done by the complaints officers, but there is clear concern about trivial or petty complaints resulting in information which is unfairly prejudicial forming part of any permanent record maintained by the Law Society for a particular member.

Although extensive statistics are presently unavailable, the Law Society has kept some records which reflect the large number of calls which have been received by the 
complaints officers. During the first seven months of the program, each office received in excess of 850 calls or letters of complaint; that translates into an average of roughly twenty to thirty new complaint calls per week per complaints officer. The trial project began in June of 1994, and therefore only operated for seven months of that year. As noted previously, the number of formal complaints for the 1993 year was 1110, and the number for 1994 was 951 - a decrease of approximately 15 percent. The figures for the first quarter of 1995 (the most recent available at the time of writing) indicate a reduction in formal complaints from 395 for the first quarter in 1994 to 309 for 1995, a decrease of approximately 23 percent. This decrease has been the first substantial drop in several years, and while it cannot be proven that the complaints officers were a factor in the reduction, it would seem to be a logical conclusion to draw.

During the first year of the trial project, two things have become apparent, these being that a large number of calls are being received in each city and that the project appears to have had an effect in reducing the number of formal complaints. As a result, the Society has now hired two additional part-time complaints officers, so that there will be the equivalent of a full-time position in each of Calgary and Edmonton.

The breakdown of complaints by area of law for the Edmonton office is as follows:

\begin{tabular}{ll} 
AREA OF LAW & PERCENT \\
Family Law & 25 \\
Civil Litigation & 17.25 \\
Real Estate & 17.25 \\
Other & 13 \\
Criminal Law & 12 \\
Corporate & 4 \\
Wills \& Estates & 4 \\
Motor Vehicle Accidents & 3 \\
Taxation & 2 \\
Malpractice & 1 \\
Immigration & 0.5 \\
Labour & 0.5 \\
Wrongful Dismissal & 0.5 \\
& \\
\cline { 2 - 2 } & 100.00
\end{tabular}

In Calgary, the similar percentages are:

Family Law

Civil Litigation

Real Estate

Other

Criminal Law

Corporate 


$\begin{array}{lc}\text { Motor Vehicle Accidents } & 2.5 \\ \text { Malpractice } & 13.75 \\ \text { Immigration } & 1.25 \\ \text { Bankruptcy } & 2.50 \\ \text { Competence } & 8.75 \\ & \\ & 100.00\end{array}$

The above numbers were taken from those actual complaints where a recording entry was made and as a result, only reflect a portion of the matters dealt with. Differences between the two complaints officers in categorizing a particular complaint also account for some of the differences in the percentages between the two offices - what one may characterize as civil litigation, the other might characterize as competence, and civil litigation frequently involves motor vehicle accidents.

In Calgary, the majority of complaints have been directed towards sole practitioners or those in an association of less than five lawyers, while the Edmonton experience has been that complaints have been received against lawyers in firms of all sizes. In many cases in Calgary, the complaints officer has noted that many of the complaints tend to involve lawyers with limited practice experience who have taken on work beyond their competence.

The project has been well received by the majority of lawyers with whom the complaints officers have been in contact, as well as by the majority of complainants who have called the Society and been put in touch with the complaints officers. The lawyers, of course, are never pleased to receive a telephone call advising them of a complaint, but given that the alternative is a registered letter from the Deputy Secretary bearing the dreaded "PERSONAL AND CONFIDENTIAL" notation on the envelope, a phone call from the complaints officer is seen as a preferable alternative. As well, a number of lawyers who have called to complain about other lawyers have indicated they are hesitant to report their fellow lawyers, but at the same time they have a dispute and need some assistance to resolve the situation. In some cases of lawyer vs. lawyer disagreements, we have suggested that confidential mediation may be available through the office of the Practice Advisor and it is understood that in some instances this suggestion has been followed. In other cases, often because of client involvement, lawyers have suggested to us that informal resolution through our office would be preferable. A significant number of these sorts of calls have been received during the first year of the project.

While the experiment has been successful enough that a decision has been made to make the complaints officers a permanent part of the Law Society complaint process, consideration should also be given to possible criticisms of the complaints officers positions and the resolution processes employed. One concern which has been raised is whether by allowing complainants to make their complaint by telephone (as opposed to the previous requirement for a written complaint), it is too easy for complaints to be made. There may be some validity to that argument, in that some complainants have attempted to use the threat of a complaint to try and force a solution to what they see 
as the problem they have with their lawyer. Examples of this are attempts to persuade a lawyer to reduce his or her fees, or to require the lawyer to provide services free of charge. Others try to obtain a free second opinion from the complaints officers. However, despite the motives, the client has become dissatisfied enough to call the Society to enquire about the complaint process, and is therefore already considering proceeding with a complaint. Requiring a written complaint may simply harden their position, thereby reducing the likelihood of resolving the situation in an informal way. In addition, if the complaints officer is unable to resolve the complaint informally, he or she will then suggest to the complainant that if the complaint is to be pursued further, a letter detailing the complaint is to be provided to the Deputy Secretary to initiate the formal process. That part of the Society's process has not been affected in any way by the complaint resolution project.

Another obvious concern is the cost of the complaints officers' salaries and that of their support staff. While it will take several years for the effects of the trial project to be clear, if the resolution process is successful, it should result in a reduction in the number of formal complaints received, thereby reducing the costs of that part of the system. In addition, the percentage of complaints which required the involvement of benchers has historically been very high (particularly appeals from dismissals made by the Deputy Secretary). It would clearly be useful (and cost-effective) to reduce the complaints requiring bencher involvement. It may never be possible to precisely balance the costs of complaint resolution against the costs of handling the complaints in the more formal way, but given the very positive response to the project, it can certainly be argued that the project is worth some increase in the costs of dealing with public or lawyer/lawyer concerns. One indirect saving was realized during the term of the experiment when several complaints involving the same lawyer led to the audit department being invited by the complaints officer to do an examination of the member's trust records. Unfortunately, a shortage was discovered and the member was suspended. Who knows how much greater the shortage might have been or how long it might have taken to discover, absent the complaints being dealt with expeditiously.

A more practical criticism, at least during the trial project, is that both complaints officers have found that the volume of calls received was greater than we were able to respond to efficiently. That in turn negatively affected both the promptness and the effectiveness of our response to complainants and to lawyers. However, the trial project was intended to test the volume of calls and the time commitment required, so presumably that should be considered as part of the experimentation process. The Society has now committed to establishing two part-time officers in each of Calgary and Edmonton, resulting in one full-time equivalent position in each city. This measure should substantially reduce the delay in responding to calls which has been experienced to date.

\section{COMPARISON TO OTHER JURISDICTIONS}

Several other law societies in Canada have established some form of complaint resolution process. Some of these are more formal than others and they vary 
substantially in the procedure adopted. The degree of success has also varied from province to province.

In British Columbia, a telephone complaint resolution (T.C.R.) process was adopted several years ago. However, instead of establishing separate complaints officers to handle the resolution function, the Law Society of British Columbia's staff lawyers handle both the formal complaints and complaint resolution. British Columbia has roughly one third more lawyers than Alberta and the Society employs seven staff lawyers in its discipline department. In 1993 it received 1,341 complaints, as well as 178 public enquiries, for a total number of 1,519 files. Of that number, 10.8 percent were either reconciled or resolved between the lawyer and the client, without the necessity for further action by the Society. However, the number of those identified as having been resolved specifically through the T.C.R. process was substantially lower. The 1994 figures provided by the Law Society were unofficial figures, but indicated that less than 3 percent of the complaints closed were specifically identified as T.C.R. files. That figure does not include the inquiries and concerns which are resolved by the Complaints Officer for the Law Society of B.C. This individual is not a lawyer, although through on-the-job training she has acquired extensive experience in legal matters and a great deal of experience in dealing with the public. She attempts to provide an initial response to all incoming telephone inquiries and, where possible, resolves the concern without the involvement of a staff lawyer. In addition, staff lawyers advised us that they often deal with complaints through a combination of T.C.R. and more formal techniques.

In our discussions with the staff lawyers in British Columbia, they have expressed concern that insufficient time is being devoted to their T.C.R. process, because in many cases the staff lawyers are handling a large number of complaints at any one time and the complaint resolution process can be much more time-consuming than dealing with the complaint in the more formal (written) way. Because of the time constraints faced by the staff lawyers, there may be a tendency to direct complaints into the formal system, simply for lack of resources (i.e. time) to attempt T.C.R. Given the realities of today's budget constraints, there will never be the resources (both people and time) that each society would like to have to devote to complaint resolution. The question then becomes whether it is more effective to have the same staff lawyers dealing with both the formal process and T.C.R., or whether the two are better separated.

Ontario is another province where the functions have been separated, although their system is somewhat different again. The Law Society of Upper Canada employs two law clerks (who are not lawyers), whose function is strictly limited to their form of T.C.R. The law clerks, who have received special training in mediation and alternative dispute resolution, are described as a part of the Intake Unit within the formal complaints process, and the Society estimates that T.C.R. is used in approximately 20 percent of all complaints received. Under their format, when the complaint is identified as being one which is suitable for informal resolution, the complainant and the lawyer are contacted and efforts are then made, primarily by telephone, to resolve the complaint. The paperwork and records are kept to a minimum, although certain internal computer codes are used to identify complaints that have been resolved through T.C.R. 
The T.C.R. project in Ontario was started in 1991 and is perceived as having been a very successful innovation, which has had a long-term effect on reducing the numbers of complaints which proceed through the formal system. The Law Society of Upper Canada has approximately 16,000 members, and in 1994 it received 5,513 complaints. Due to a number of factors, including the recession and an increase in public awareness of the Law Society's role, the number of complaints per year has varied widely over the last five years, from a low of 4,175 in 1990 to a high of 5,803 in 1992. It is therefore somewhat difficult to clearly identify a specific reduction in formal complaints as a result of T.C.R. However, it is the perception of the Society that the process has resulted in a clearly detectable reduction in formal complaints. Approximately 1,000 of the complaints received in 1994 were resolved through the T.C.R. process.

In Manitoba, the Law Society initiated a telephone mediation system on a trial basis in the spring of 1993. From that time until December 1994, the Society estimated that over 100 complaints had been successfully mediated. ${ }^{15}$ The Society has indicated that "[i]t is hoped that within the coming year 25-30 percent of all complaints will be dealt with by way of telephone mediation." ${ }^{16}$ The Rules of the Law Society of Manitoba ${ }^{17}$ have been specifically amended to allow for mediation. Under their rules, upon receipt of a complaint the chief executive officer must make an initial determination that a complaint either does or does not merit investigation. Where the complaint merits investigation, an attempt to mediate the complaint is then an alternative to the formal notice to the member of the complaint. Their Rules state:

31 Where the chief executive officer or the complaints commissioner determines that a complaint merits investigation, the chief executive officer shall

(a) send a letter to the member complained of enclosing a copy of the complaint and requiring a written answer, or

(b) attempt to mediate the complaint where

in the opinion of the chief executive officer, the complaint may be satisfactorily resolved without requiring a written answer from the member, and

(ii)

the complainant and the member complained of consent to mediation. ${ }^{\text {Is }}$

The Rules provide that if the mediation is successful, written confirmation shall be provided to the complainant and the member and no further action shall then be taken. If the mediation is unsuccessful, the complaint is then dealt with under the formal complaint procedure. Manitoba's procedure is somewhat more formal than that of some

D.J. Scarth, "Mediation Experience A Success" The Law Society of Manitoba Communique (December 1994/January 1995) 4 at 4.

16

Ibid. at 5 .

17

18

Law Society of Manitoba, Rules of the Law Society of Manitoba in Handbook of Professional Conduct (Winnipeg: Law Society of Manitoba, 1990).

Ibid., r. 31 (in Part Vl - Complaints). 
other provinces, in that they will not consider mediation unless the complaint is first received in writing. Once the complaint has been initially made in writing, the mediation will often proceed by way of telephone contact, but they will not accept the initial complaint by way of the telephone. There may be several considerations which support this position (for example, the written complaint forces the complainant to clarify the specific basis of the complaint and thereby potentially reduces the number of issues on the table, and the staff person receiving the complaint is somewhat protected in terms of clarifying the complaint which he or she has in fact received). However, there are also arguments in favour of accepting telephone complaints, the most obvious being that requiring the complainant to reduce the complaint to writing may well harden his or her position and increase the frustration and anger with both the lawyer and the system. This in turn may reduce the likelihood of successful mediation.

In Saskatchewan, no formal mediation or complaint resolution process has yet been attempted, but the benchers are actively considering the issue and the experience of other jurisdictions with the process.

In considering the experience of law societies outside Canada, the most comparable jurisdiction is probably that of the law society which governs solicitors practicing in England and Wales. The law society there has delegated its authority to investigate complaints to the Solicitors Complaints Bureau, an independent body which was established in 1986. Interestingly, the Bureau has moved significantly from what they describe as being initially the role of "the policeman of the profession," to a role which places much greater emphasis on conciliation of complaints. In an "Information Pack" provided to solicitors to help them avoid complaints, the Bureau states, "Our ultimate aim is to reduce the number of complaints coming into the Bureau ...[i]t is much cheaper for problems to be sorted out at source."19 The material provided to solicitors is remarkably similar to the information which has been circulated by the Alberta Law Society, indicating the need for some form of alternative dispute resolution (ADR) to deal with complaints. In summarizing the British experience, the Bureau noted:

the Bureau was receiving a rising number of complaints many of which required bridge building by the Bureau rather than a heavy truncheon. While there is still a need to exercise the disciplinary function a new approach had to be tried. This has led to a re-structuring of the Bureau to place more emphasis on conciliation. ${ }^{20}$

In reviewing the present practice and the number of complaints dealt with in the conciliation process, the Bureau states:

Because less than ten per cent of the Bureau's workload went before the Adjudication Committee under the old structure there was a belief held by some sections of the profession that this meant that 90 per cent of the other complaints were unjustified. 
This is not so. It is true that very many of these matters are resolved by a couple of telephone calls. A misunderstanding about the statutory charge cleared up here, an explanation proffered there, a promise extracted from some firm to progress matters immediately over there, are all among the $\mathbf{9 0}$ percent of complaints currently going through the conciliation process which is resolving four fifths of the Bureau's case load."

Clearly, the experience in England and Wales has been that a high percentage of complaints received can be resolved without recourse to the formal system, although the formal system is still available if needed. The material published by the Bureau indicates that one of the strongest factors encouraging conciliation as opposed to more formal discipline is the relative cost to the profession, which is ultimately responsible for its own self-discipline.

\section{CONCLUSION}

At the beginning of the trial project in Alberta, there was no announcement to the public of either the project itself or any change to the Society's processes. The profession was advised through an article published in the Bencher's Advisory of July 1994. ${ }^{22}$ Following that, one daily newspaper carried a brief article describing the experimental project and the complaints officers' role. ${ }^{23}$ Despite the lack of any wide announcement, the complaints officers have received an overwhelming number of calls, with a similar pattern to the calls received in both Calgary and Edmonton. The experience of the Society during the first year of the experiment would indicate that a need existed in the complaint process which was not previously being met.

The majority of both the public and the lawyers with whom the complaints officers have had contact have responded very favourably to the attempt to resolve complaints on an informal basis. In dealing with complaints, the cliché that "you can't please all of the people all of the time" certainly applies, but by providing one positive alternative to individuals seeking assistance, the Law Society is serving both the public and the profession. As the English Solicitors Complaints Bureau states:

Effective self-regulation is essential to the well-being of the solicitors' profession. But its upholders, solicitor and lay, paid and unpaid, do not expect to win easy popularity. Treating complaints, and therefore the public interest seriously, can be resource-intensive and time-consuming. It can call for the judgement of Solomon and a flak jacket. However, for the good of both the public and of the profession, we have to make it work. Only by striving constantly to improve our own standards, and as a consequence those of the profession, can we demonstrate that it does. ${ }^{24}$

"Portrait of a Complainant" in Solicitors Complaint Bureau Information Pack, ibid. [emphasis added].

22 "Complaint Resolution Project" Law Society of Alberta Bencher's Advisory (July 1994) 1.

$23 \quad$ H. Dolik, "Complaint officers hang out Law Socicty shingle" The Calgary Herald (10 September 1994) B1.

24 Solicitors Complaints Bureau of England and Wales, Annual Report 1993 (London, U.K.: Solicitors Complaints Bureau, 1993) at 3. 
In conclusion, we are acutely aware that many complainants do not hold the legal profession in very high regard and unfortunately in some cases this is justified. On the other hand, our experience has been that the vast majority of lawyers practicing law in Alberta are capable, responsible professionals who do their best to assist their clients and to advance the client's interests in dealing with a wide variety of problems. This is a challenging role, and given the emotional stresses which are often intrinsically part of the legal situation, it is not surprising that in some cases problems develop. As the complaints officers, we have received both personal and professional satisfaction in resolving complaints where our efforts have been successful. Where our efforts have not been successful, we know that we have done what we could to help those concerned and the profession generally. Balancing our understanding of the stress on lawyers caused by our self-disciplining role and the need to provide a human, effective response to the public's complaints is a responsibility the Law Society takes very seriously, and will continue to strive to improve. 